\title{
Perceptions of Accountants toward Sustainability Development Practices in Bangladesh
}

\author{
Emon Kalyan Chowdhury ${ }^{1} \&$ Shafaitun Nahar ${ }^{1}$ \\ ${ }^{1}$ Department of Accounting, Faculty of Business Studies, Premier University, Bangladesh \\ Correspondence: Emon Kalyan Chowdhury, Department of Accounting, Faculty of Business Studies, Premier \\ University, Bangladesh. E-mail: emonkalyanchy@gmail.com
}

$\begin{aligned} & \text { Received: July 10, } 2017 \quad \text { Accepted: July 27, } 2017 \quad \text { Online Published: August 3, } 2017 \\ & \text { doi:10.5539/jms.v7n3p112 }\end{aligned} \quad$ URL: http://doi.org/10.5539/jms.v7n3p112

\begin{abstract}
This study aims to gauge the perceptions of accountants in Bangladesh toward sustainable development practices in their respective organizations. The perceptions are assessed by collecting data from accountants of different organizations through a structured questionnaire. It finds that loyalty and commitments between employers and employees stimulate the practices of sustainability development in an organization. It also finds that accountants are extremely passionate to implement required instructions for sustainability but they are chained by traditional mind set of top management and profit-centric policies of organizations. In some organizations, despite management interest, implementation is hindered by lack of sufficient guidelines for sustainability development. The outcome of this study will help accountants to keep themselves up-to-date on various aspects of sustainable development practices and also help them to have a clear scenario of sustainability practices in Bangladesh.
\end{abstract}

Keywords: accountants, sustainability reports, CSR, laws, barriers

\section{Introduction}

Sustainability implies the impact of organizations' activities on the earth, people and its probable future consequences. The essence of sustainability lies in the commitment of organizations to meet the present needs without hampering the ability of meeting the needs of future generations. It also represents the activities of human being that affect people, society, economy and environment of a given territory. Many people think sustainable development means discharging corporate social responsibility (CSR), ensuring compliance of corporate governance and doing the right things. In practice, whether an activity is sustainable or not it is difficult and complex to explain. The issue sustainability reporting, came to the light in the year 2000 . Organizations need to report sustainability focusing on three vital elements viz., environmental, social and economic performance. Environmental reporting includes balancing the biodiversity. Social issue includes labor law, product responsibility, policies regarding human rights, and industrial relations. Economic issue covers productivity, employment diversity, employment generation, training requirement etc.

Sustainable development has become a prime concern for most of the organizations. Their aim is to make the operations sustainable in the long-run. Sustainability reporting make their aim achievable through proper measurement, communicating the economic facts, discharging the responsibilities towards society etc. Sustainability report benefits an organization in several ways. It measures the effects of their operations on the society and environment. Organizations can set appropriate objectives to manage the change. It helps an organization to continue its business with satisfactory profits through ethical behavior, ensuring social justice and taking ultimate care of environment. Denmark is the first country which made environmental reporting compulsory followed by Netherlands, Norway, Sweden etc. Government of Bangladesh enacted Bangladesh Environment Conservation Act-1995, and Environment Conservation Rules-1997. Under these acts companies are required to disclose environmental information. Moreover, Company Act-1994 and the Bangladesh Chartered Accountants Order-1973 also provide legal framework for accounting and reporting requirements of listed companies in Bangladesh. Bangladesh is passing through a tough time for degrading environment due to industrial activities (Ullah, Yakub, \& Hossain, 2013). As a part of sustainability development reporting system, corporate social responsibility (CSR) was a matter of self-interest for the corporate sector (Azim, Ahmed, \& Islam, 2009) but now it is a great concern of most of the organizations in Bangladesh (Azim, Ezaz, \& Brian, 2011). The practice of CSR by ensuring quality and quantity of social corporate disclosure and transparency is a time demand in Bangladesh. The regular practice of CSR directly increases the revenues of a company and 
enhance the interest of stakeholders at large. The practice is very poor in Bangladesh comparing to global organizations (Miyan, 2006).

\section{The Role of Accountants from Literature Perspective}

The term sustainable development shapes to the path for human progress that has the capacity to continue. In today's world economy, one of the most significant phenomenon is sustainable development. The cognizance of sustainability has gained universal attention in the wake of the announcement by The World Commission on Environment and Development, published under the title "Our Common Future" in 1987, and also recognized as the Brundtland Report. According to the report, "Sustainable development is democrat as meeting today's needs without creating a threat for the needs of upcoming genesis to meet their own needs." Sustainable development is commonly presented with three areas. These areas are divided into environment, society and economy. It is the simultaneous progress of our economic, societal and ecological objects that is indispensable if development is to be sustainable. Integrating sustainable development, therefore, means organizing intellectual and pragmatic tools that make it feasible to think about all the substance of sustainability together. The more individual decisions are made in that context, rather than in isolation, the more they are likely to contribute positively to sustainable development. In order to shift onto a sustainable development track, it will be necessary to develop intellectual and pragmatic tools that enable us to think about, and then progress simultaneously our economic, social and environmental goals. Sustainability accounting techniques are a fundamental part of this process.

The preface of businesses in the realization of sustainability objectives was particularly emphasized in the second Earth Summit, which was seized in Johannesburg in 2002 after the declaration of the Brundtland Report (1987). This announcement has led the business world to acknowledge the requisite for close monitoring and internalization of the topics of sustainability and sustainable development. Development levels of states vary pointedly from each other across the world.

Technological advancement, trouble-free transfer of technology, financial sources and financial liberalization are a number of the factors that affect the economies of nations and their levels of growth. Furthermore, these changes create new environment for corporations to accommodate to. As an outcome of these development businesses orientation ability and appraisal system should be based on both economic and non-economic information.

This new environment creates perceptions among the stakeholders, especially the customers about the societal and ecological phenomenon. In the new inclinations companies are ultimately responsible for meeting the needs of both shareholders and all others stakeholders to continue their existence (Aras \& Crowther, 2008; Porter \& Kramer, 2003). An Accounting information system is a procedure which is responsible to assemble, stock, supervise, handle and report its financial data for both external and internal parties. Traditionally, this system is emphasized on financial performance, designed to report profit. But Sustainability embrace all forms of life that share the world to represent a multidimensional perspective whether they are mutually interrelated or not, and it also performs some duty of collective integrity between and within generation through the preservation and maintenance of finite and crucial environment.

Accountants and accounting need to improve additional qualitative and quantitative expertise in regulate to denote sustainability, with its economic and environmental elements along with the social ones. To perform its fundamental functions and improvement of new skills reflect the responsibility of accounting in sustainability. The accountant's role may change based on the circumstance's demand.

Now it is being involved in environmental benefits program and social issues, such as cost reduction and revenue generation, and appraising investment proposal. It also provides some stipulation of ecological management. Now they are responsible for reporting ecological and societal information along with financial data to their stakeholders and by other ways of communication, thus, supporting the determination, growth and action of the mechanisms that constitute the infrastructure of sustainability.

Burnett \& Hansen (2008) and Myburgh (2001), state that Pragmatic evidence demonstrate that accountant and accounting practices acted as facilitator of decision making because the association between ecological and economic performance has increased, and also with innovative performance methods and investigation tools integrating Environmental matters into their parts as a performance measures and analytical gears.

Wilmshurst \& Frost (2001) argued that involvements of accountants in accounting for sustainable development are not appreciable. Because of their confined knowledge they don't work as a member of the sustainable development team. Moreover, they pointed that sustainable development could abstract accounting structure that evaluate both the risks and opportunities presented by sustainability issues, including ecological and societal aspects that ultimately influence economic performance. 
From the above argument, two-dimensional roles can be emerged for the accountant. Accountants can provide information to decision makers, concentrating on company's internal operations, strategy formulations and for purpose of decisions making. Accountants can also furnish information to individuals and groups both inside and outside the organization in order to help them assess its financial performance through the preparation of economic report. CIMA (1981) argued that to assemble the needs of present situation accountant need to attain an additional starring role in sustainable development. The CIMA (1981) report on "The job of the Accountant for sustainability" emphasized on the accountants informational, decisional and strategic roles within organizations. The report illustrated the concepts that accountants can take a more effective role in strategic arrangement around sustainable development. While present literature review call for accountants to be more collaborative and acted as a decisions facilitator within organizations, research illustrious that little awareness has been paying on accounting practices and engagement of accountant for sustainable development.

There are many underlying causes why accountant need to join in development initiative for sustainability. First being calls for accountants to assist organizations respond to natural effects and dependencies, otherwise the sustainability of organizations will be under threat. Second being calls for a leadership role accountant can play in embedding sustainability elements into an organization's strategy and decision-making processes to achieve sustainable value creation. Third reason is accountants can create greater consciousness of sustainability and society's perceptions of sustainable development.

From the above discussion, it is observed that the sustainability development reporting guidelines are not appropriately paired with the perceptions of accountants. This study will throw lights on few vital questions which will be helpful to bridge the gap between accountants' perceptions and sustainable development practices. The research questions are as follows;

First question: what are the perceptions of accountants towards their role for sustainable development?

Second questions: which factors drive accountants toward practicing sustainable development?

Third question: what are the barriers confronted by accountants to be involved in sustainable development activities?

\section{Research Methods}

The primary data have been collected from 30 respondents who work as accountant in different organizations and play vital role in their respective organizations as decision maker. A customized structured questionnaire instrumented by Dimitrov \& Davey (2011) has been used to collect data focusing on different aspects of sustainability reports. The questionnaire which was prepared aiming at the role and involvement of accountants toward sustainable development issues. To collect the data, google doc based survey facility was used emailed to 35 accountants of different organizations. However, 30 of them filled up the forms successfully and submitted. The respondents are belonging to diverse sectors and representable as far as exploratory research is concerned. The questionnaire was designed by Likert scale starting from 1 to 5 . Where 1 indicates strongly disagree and 5 indicates strongly agree and other points in between. It focused on three important areas of sustainability development reports, like drivers for sustainable development, perceived barriers in sustainable development and types of sustainable development practices. Respondents were given necessary information about the research topic over the phone. They also contacted researchers to clear their doubts on questions while filling up the survey form. Since, google doc facility was used, all the submitted forms were complete.

\section{Findings}

This segment demonstrated the consequences from the survey data. Toward sustainable development different aspects are emerged about the roles of accountants, barriers to involvement in development practices and the types of development practices accountants need to be implement. The study emphasized on the accountants' perceptions about their roles, and barriers towards sustainability practices. Since the total population enthusiastically responds to the survey without any biasness, key role of accountants for sustainable development can easily be determined from the results exposed by survey. However, potential role of accountants is prejudiced by the organizational environment they are employed. 
Table 1. Respondents by industry

\begin{tabular}{llllll}
\hline Sector & No. of respondent & per cent & Sector & No. of respondent & per cent \\
\hline Bank & 4 & 13.3 & Merchandiser & 2 & 6.7 \\
Cement & 2 & 6.7 & Paper & 1 & 3.3 \\
Education & 4 & 13.3 & Pharmaceuticals & 1 & 3.3 \\
Garments & 5 & 16.7 & Steel & 2 & 6.7 \\
Insurance & 2 & 6.7 & Telecom & 1 & 3.3 \\
IT & 3 & 10.0 & Total & 30 & 100.0 \\
Manufacturing & 3 & 10.0 & & & \\
\hline
\end{tabular}

Table 1 lists the organizational backgrounds of respondents. It is observed that majority of applicants work within the Garments industry then trailed by the banking and education sectors. Third sector trailed by IT and manufacturing industry. The minority of applicants working within merchandising, insurance, steel, paper pharmaceutical and Telecommunication industries of Bangladesh.

Table 2. Respondents by organization type

\begin{tabular}{lll}
\hline Type & No. of respondent & per cent \\
\hline Government & 1 & 3.3 \\
Listed Company & 15 & 50.0 \\
Private & 14 & 46.7 \\
Total & 30 & 100.0 \\
\hline
\end{tabular}

Table 2 displays the type of organization structure from which the applicants were surveyed. Chart 2 displays 50 per cent of survey applicants worked in listed company, 46.7 per cent working in the private company and 3.3 per cent working in the government organizations. According to Sec. 2 (1) (q) of the Companies Act, 1994 provides, "Private company means a company which by its articles-Restricts the right to transfer its shares, if any, prohibits any invitation to public to subscribe for its shares or debenture, if any, Limits the number of its members to fifty not including persons who are in its employment." Invitation to public to subscribe for its shares is not allowed. Government Company means a Company of which not less than 51 per cent of the paid-up capital is held by the Central Government of by State Government or Government singly or jointly. It includes a company subsidiary to a government company. The share capital of a government company may be wholly or partly owned by the government, but it would not make it the agent of the Government. Table 3 reveals accountants' perceptions about the sustainable development drivers in Bangladesh. The table demonstrate that of the 30 applicants surveyed, on average "Practice of sustainable development enhance organizational image" was deliberated the robust driver for sustainable development. This issue was counted the highest ranked category, with 66.7 per cent of applicants strongly agreeing and 26.7 per cent applicants agreeing with the statement as being the main driver. Similarly, this statement generated a median of 5 and the maximum mean of 4.5333 . Through the collaborative efforts, accountant can arrange for mechanisms for holding an organization accountable and enhancing the organization's image (Wilmshurst \& Frost, 2001; Tilt, 2009). The lowest graded driver category supposed by accountants was "sustainability report ensures smooth excess to the financial market" with a mean of 3.833 and a median of 4 . A survey of the consequences demonstrates that 53.3 per cent only agreed with the requirement of sustainability report for ensuring smooth excess to the market, a total of 6.6 per cent disagreed and 20 per cent of respondent were "neither agree nor disagree". This result is conflicting to the literature, as per it is suggested that sustainability report provides information to individual and groups both inside and outside the organizations about the environmental and social aspects that ultimately effect economic performance and through these reports they can judge its financial performance for accessing to the financial market. Third driver was "it is important to follow the prevailed laws that govern environmental issues". The results of the survey revealed that 63.3per cent participants strongly agreed with the statement and only 3.3per cent strongly disagreed. There are many established policies in Bangladesh like Environmental Conservation Act 1995, Environmental Conservation Rules 1997. Bio medical waste management rules, 2008. 
Table 3. Perceptions about drivers for sustainable development

\begin{tabular}{|c|c|c|c|c|c|c|c|c|c|c|c|c|c|}
\hline & \multicolumn{2}{|c|}{ Strongly Disagree } & \multicolumn{2}{|c|}{ Disagree } & \multicolumn{2}{|c|}{ Neutral } & \multicolumn{2}{|c|}{ Agree } & \multicolumn{2}{|c|}{ Strongly Agree } & \multirow[b]{2}{*}{ Median } & \multirow[b]{2}{*}{ Mean } & \multirow[b]{2}{*}{ Ranking } \\
\hline & per cent & Number & per cent & Nunber & $\begin{array}{c}\text { per } \\
\text { cent }\end{array}$ & Number & $\begin{array}{l}\text { per } \\
\text { cent }\end{array}$ & Number & per cent & Number & & & \\
\hline $\begin{array}{l}\text { Practice of sustainable development enhances } \\
\text { organization's image }\end{array}$ & 3.3 & 1 & 0 & 0 & 3.3 & 1 & 26.7 & 8 & 66.7 & 20 & 5 & 4.53 & 1 \\
\hline $\begin{array}{l}\text { Sustainability report ensures smooth access to the } \\
\text { financial marke: }\end{array}$ & 3.3 & 1 & 3.3 & 1 & 20 & 6 & 53.3 & 16 & 20 & 6 & 4 & 3.83 & 3 \\
\hline $\begin{array}{l}\text { It is important to follow the prevailed laws that govern } \\
\text { environmental issues }\end{array}$ & 3.3 & 1 & 0 & 0 & 10 & 3 & 23.3 & 7 & 63.3 & 19 & 5 & 4.33 & 2 \\
\hline
\end{tabular}

Table 4. Perceptions of factors of most importance for organizations to achieve sustainable development.

\begin{tabular}{|c|c|c|c|c|c|c|c|c|c|c|c|c|c|}
\hline & \multicolumn{2}{|c|}{ Strongly Disagree } & \multicolumn{2}{|c|}{ Disagree } & \multicolumn{2}{|c|}{ Neutral } & \multicolumn{2}{|c|}{ Agree } & \multicolumn{2}{|c|}{ Strongly Agree } & \multirow[b]{2}{*}{ Median } & \multirow[b]{2}{*}{ Mean } & \multirow[b]{2}{*}{ Ranking } \\
\hline & per cent & Number & per cent & Number & $\begin{array}{l}\text { per } \\
\text { cent }\end{array}$ & Number & $\begin{array}{l}\text { per } \\
\text { cent }\end{array}$ & Number & per cent & Number & & & \\
\hline $\begin{array}{l}\text { Organization should retain resourceful employees for } \\
\text { its own benefits }\end{array}$ & 3.3 & 1 & 0 & 0 & 0 & 0 & 23.3 & 7 & 73.3 & 22 & 5 & 4.63 & 1 \\
\hline $\begin{array}{l}\text { Investors like to buy shares of those companies which } \\
\text { are involved in activities related to sustainability }\end{array}$ & 0 & 0 & 6.7 & 2 & 36.7 & 11 & 30 & 9 & 26.7 & 8 & 4 & 3.77 & 3 \\
\hline $\begin{array}{l}\text { Organization should take necessary precautions to } \\
\text { prevent environment pollution }\end{array}$ & 3.3 & 1 & 3.3 & 1 & 0 & 0 & 13.3 & 4 & 80 & 24 & 5 & 4.63 & 1 \\
\hline $\begin{array}{l}\text { Organizations in Bangladesh need to comply with } \\
\text { different rigid conditions imposed by their foreign } \\
\text { counterparts }\end{array}$ & 3.3 & 1 & 13.3 & 4 & 30 & 9 & 36.7 & 11 & 16.7 & 5 & 4 & 3.5 & 4 \\
\hline $\begin{array}{l}\text { Adaptation of sustainable development leads to } \\
\text { growth of new technology }\end{array}$ & 3.3 & 1 & 0 & 0 & 13.3 & 4 & 50 & 15 & 33.3 & 10 & 4 & 4.1 & 2 \\
\hline
\end{tabular}

Bangladesh climate change and strategy and action plan, 2009. The above policies, plans and instruments are contributing or will do so in near future to social, economic and environmental advancement if it followed properly. The high grading provided aspects such as Without sustainable practices it is incredible to enrich organizational image," "laws that govern environmental issues", sustainability report ensures smooth access to the financial market, prove that the driver of sustainable development is to gain acceptability from participants with the aim of obtain continuous provision for organizations' action. This driver helps corporate organizations in keeping a praiseworthy appearance of themselves in the community and drives them towards development. This paper provides option to the participants to express their opinion on the most important factors were in an organization to account for sustainable development. Table 4 demonstrate the findings for this issue. The results revealed that most of the participants were considered two important issues "organization should retain resourceful employees for its own benefits" and "organization should take necessary precautions to prevent environmental pollutions" as the most important factors for sustainable development. Both the issues yielded the highest mean of 4.6333 and a median of 5. The result related to the issue "retention of resourceful employees" Shows that 73.3 per cent participants strongly agreed, 23.3 per cent agreeing with the employee retention only 3.3 per cent disagreed. This finding also complements with our literature. Literature review reveals that organization can attract and retain resourceful employees through creating an image of sustainability in the eye of employees (Battacharya, Sen and Korschun, 2008). The other issue "organization should take necessary precautions to prevent environmental pollutions" as the most important factors for sustainable development". It gained 80 per cent support from strongly agreed, 3.3 per cent from strongly disagreed. Bangladesh has been facing degradation of the natural environment in terms of deforestation, water and air pollution, pollution from chemical fertilizer and industries and above all, frequent climatic changes, as a results global warming are increasing in a devastating way. At present Bangladesh needs to become progressively more aware of the looming environmental rise due to the increasing extreme climate change and other degradation factors. Environment being one of the three pillars of sustainable development along with social and economic pillar, must achieve appropriate attention in relation to environmental protections and response to the climate changes. Bangladesh has been trying to promote an integrated approach, involving all the three pillars of sustainable development, with the human being at the center of the state. Indeed, the ultimate goal is an inclusive society in which human dignity will be ensured for every citizen.

The lowest ranked factor perceived by accountant was "organizations in Bangladesh need to comply with different rigid condition imposed by their foreign counterparts" with a mean of 3.5 and a median of 4 . A perusal of the result shows that while only 13.3 per cent strongly agreed to comply with different rigid conditions imposed by their counterparts. Most of the participants about 30 per cent were neither disagree and nor agree. From the analysis, it is emerged that this factor considered as important one for attaining sustainable development. Almost 36.7 per cent participants agreeing with this statement that it has miniature effect on an organization's vision of sustainable development,

Again, from table 4 it was revealed that "Adaptation of sustainable development leads to growth of new 
technology" ranked second, with an average median of 4, here 50 per cent participants agreeing and 33.3 per cent strongly agreed on practices of sustainable development for enriched our technological growth. The third category ranked was "investors like to buy shares of those companies which are involved in activities related to sustainability". This category scored 30per cent support from agreed and 26.7 per cent from strongly disagreed. The minority of responses almost 36.7 per cent were "neither agree nor disagree". All of the above factors suggest that organizations tend to conform to these to create sustainable image and to achieve acceptability from both their legal and other external stakeholders.

Table-5 identified the perceived barriers for accountants in accounting for sustainable development. The results revealed that on average the highest ranked category as the greatest barrier against accounting for sustainable development for accountants was that "Necessary management support and commitment are required to implement sustainability practices".

The question gained equal positive and negative support across the participants. From the participants, it scored 53.3 per cent support for strongly agreed and the other 46.6 per cent support for disagreed the question. This question provides the highest mean of 4.433 and a median of 5, indicating on average participants strongly agreed with this statement. From the literature review it also agreed that lack of management support and commitment towards the sustainability practices. This ranking is further supported by the second ranking which was "there is lack of necessary guidelines to participate sustainability in Bangladesh" also scored 43.3 per cent strongly agreed and 36.7 per cent agreed support from participant that Bangladesh has no structured policy to support organizations' view towards sustainable development.

Table 5. Perceived barriers for accounting for sustainable development

\begin{tabular}{|c|c|c|c|c|c|c|c|c|c|c|c|c|c|}
\hline & \multicolumn{2}{|c|}{ Strongly Disagree } & \multicolumn{2}{|c|}{ Disagree } & \multicolumn{2}{|c|}{ Neutral } & \multicolumn{2}{|c|}{ Agree } & \multicolumn{2}{|c|}{ Strongly Agree } & \multirow[b]{2}{*}{ Median } & \multirow[b]{2}{*}{ Mean } & \multirow[b]{2}{*}{ Ranking } \\
\hline & per cent & Number & percent & Number & $\begin{array}{l}\text { per } \\
\text { cent }\end{array}$ & Number & $\begin{array}{l}\text { per } \\
\text { cent }\end{array}$ & Number & $\begin{array}{l}\text { per } \\
\text { cent }\end{array}$ & Number & & & \\
\hline $\begin{array}{l}\text { There is lack of necessary guidelines to practice } \\
\text { sustainability in Bangladesh }\end{array}$ & 0 & 0 & 13.3 & 4 & 6.7 & 2 & 36.7 & 11 & 43.3 & 13 & 4 & 4.1 & 2 \\
\hline $\begin{array}{l}\text { Necessary management support and commitment are } \\
\text { required to implement sustainability practices }\end{array}$ & 3.3 & 1 & 43.3 & 13 & 0 & 0 & 0 & 0 & 53.3 & 16 & 5 & 4.43 & 1 \\
\hline Sustainable practices involve too much of zosts & 0 & 0 & 33.3 & 10 & 36.7 & 11 & 23.3 & 7 & 6.7 & 2 & 3 & 3.03 & 3 \\
\hline $\begin{array}{l}\text { Cost of producing sustainability reports is higher than } \\
\text { that of benefits }\end{array}$ & 16.7 & 5 & 36.7 & 11 & 13.3 & 4 & 30 & 9 & 3.3 & 1 & 2 & 2.67 & 5 \\
\hline $\begin{array}{l}\text { There is no direct financial benefit for irplementing } \\
\text { sustainable practices. }\end{array}$ & 3.3 & 1 & 36.7 & 11 & 26.7 & 8 & 23.3 & 7 & 10 & 3 & 3 & 3 & 4 \\
\hline $\begin{array}{l}\text { For a small-size company, the practice of } \\
\text { sustainability is unnecessary }\end{array}$ & 30 & 9 & 33.3 & 10 & 23.3 & 7 & 6.7 & 2 & 6.7 & 2 & 2 & 2.27 & 6 \\
\hline
\end{tabular}

Table 6. Types of sustainable development practices accountants implement

\begin{tabular}{|c|c|c|c|c|c|c|c|c|c|c|c|c|c|}
\hline & \multicolumn{2}{|c|}{ Strongly Disagree } & \multicolumn{2}{|c|}{ Disagree } & \multicolumn{2}{|c|}{ Neutral } & \multicolumn{2}{|c|}{ Agree } & \multicolumn{2}{|c|}{ Strongly Agree } & \multirow[b]{2}{*}{ Median } & \multirow[b]{2}{*}{ Mean } & \multirow[b]{2}{*}{ Ranking } \\
\hline & $\begin{array}{l}\text { per } \\
\text { cent }\end{array}$ & Number & $\begin{array}{l}\text { per } \\
\text { cent }\end{array}$ & Number & $\begin{array}{l}\text { per } \\
\text { cent }\end{array}$ & Number & $\begin{array}{l}\text { per } \\
\text { cent }\end{array}$ & Number & $\begin{array}{l}\text { per } \\
\text { cent }\end{array}$ & Number & & & \\
\hline $\begin{array}{l}\text { A global sustainable reporting standard is required } \\
\text { for effective comparison }\end{array}$ & 3.3 & 1 & 3.3 & 1 & 10 & 3 & 50 & 15 & 33.3 & 10 & 4 & 4.07 & 5 \\
\hline $\begin{array}{l}\text { The sustainability reports of an organization should } \\
\text { be compared to the best performer for further } \\
\text { improvement }\end{array}$ & 0 & 0 & 3.3 & 1 & 13.3 & 4 & 46.7 & 14 & 36.7 & 11 & 4 & 4.17 & 4 \\
\hline $\begin{array}{l}\text { Compliance of ISO-14001 should be made } \\
\text { compulsory for all the organizations }\end{array}$ & 10 & 3 & 0 & 0 & 23.3 & 7 & 46.7 & 14 & 20 & 6 & 4 & 3.67 & 9 \\
\hline $\begin{array}{l}\text { It is important to analyze the perception of customers } \\
\text { toward the risk of sustainability of the company }\end{array}$ & 3.3 & 1 & 3.3 & 1 & 20 & 6 & 60 & 18 & 13.3 & 4 & 4 & 3.77 & 8 \\
\hline $\begin{array}{l}\text { It is essential for the organization to develop systems } \\
\text { to use least energy }\end{array}$ & 6.7 & 2 & 6.7 & 2 & 10 & 3 & 33.3 & 13 & 43.3 & 13 & 4 & 4 & 6 \\
\hline $\begin{array}{l}\text { There should have provision for punishment for not } \\
\text { following the standard }\end{array}$ & 0 & 0 & 6.7 & 2 & 20 & 6 & 46.7 & 14 & 26.7 & 8 & 4 & 3.93 & 7 \\
\hline $\begin{array}{l}\text { Organizations should focus on social, environmental } \\
\text { and financial aspects simultaneously for greater } \\
\text { benefits }\end{array}$ & 3.3 & 1 & 0 & J & 10 & 3 & 26.7 & 8 & 60 & 18 & 5 & 4.4 & 3 \\
\hline $\begin{array}{l}\text { Effective supply chain management can reduce } \\
\text { sustainability risk }\end{array}$ & 6.7 & 2 & 3.3 & 1 & 16.7 & 5 & 53.3 & 16 & 20 & 6 & 4 & 3.77 & 8 \\
\hline $\begin{array}{l}\text { Organization should take necessary actions to reduce } \\
\text { wastage }\end{array}$ & 3.3 & 1 & 3.3 & 1 & 0 & 0 & 30 & 9 & 63.3 & 19 & 5 & 4.5 & 1 \\
\hline $\begin{array}{l}\text { Organization should ensure appropriate uilization of } \\
\text { available resources }\end{array}$ & 3.3 & 1 & 0 & J & 3.3 & 1 & 33.3 & 10 & 60 & 18 & 5 & 4.47 & 2 \\
\hline
\end{tabular}


The question "For a small size company the practice of sustainability is unnecessary" shows the lowest ranked perceived barrier for accountant in the path of development. This issue gained 63.3 per cent disagreed support from the participant that inversely revealed positive contribution towards the development path. Median of the result was 2, indicating that implementation of sustainable development practices does not depends on the size of the organizations. The third ranking barriers against sustainable development was that "sustainability practices involve too much of costs". This statement gained 6.7 per cent for strongly agreed and 23.3 per cent for agreed support from the respondent. From point of view of Parker (2000, p. 48) in traditional accounting systems accountants only considered economic aspects of reporting but they did not measure the benefit of consumption of natural resources such as air, water and land in any monetary terms. But now accountants are trying to integrate the three pillars of sustainable development in their reporting. As a result, implementation costs of sustainable practices are increasing day by day. Simultaneously cost of sustainable practices becomes higher because the systems don't get any direct financial benefit from any sources. This statement scored 23.3 per cent for agreed and 10 per cent for strongly agreed support from participants. From the above findings, it infers that organizations should take necessary steps to overcome the barriers so that the benefits of sustainable practices outweigh the costs of the systems. Accountants prefers different types of practices in fulfilment their role in the organization. The first preferable practice that an accountant wants to implement was organizations should take necessary actions to reduce wastage. The results revealed 63.3 per cent for strongly agreed and 30 per cent agreed with this statement. This category scored the highest mean of 4.5 and median of 5. It would appear that accountants should create awareness about wastage management system. The second ranked practice was "organizations should ensure appropriate utilizations available resources". This gained 60 per cent support for strongly agreed and 33.3 per cent for agreed support from the participants. It suggested that accountant should properly calculated cost and benefit which is gained from available resources. The two lowest ranked category sustainable development practices were, it is important to analyze the perception of customers toward the risk of sustainability and effective supply chain management can reduce risk. Both these statements gained the lowest mean of 3.7666 . Only 20 per cent and 36.7 per cent strongly agreed support from the participants. The results revealed that accountants are partially involved in accounting for sustainable development. This finding shows that accountants tend not to engage in sustainable development accounting practices, as the majority of the scores were "neither".

\section{Conclusion}

This study aimed to know the perception of accountants in Bangladesh toward their role for sustainable development. It is observed that loyalty and commitments between employers and employees toward organizations and their relevant stakeholders enhance the possibility of practices that propels the sustainability of organizations in the long-run. Although literature shows accountants play vital role in framing policies for the organizations, in Bangladesh, accountants merely enjoy the power rather they follow the instructions of top brass as their wishes. In fact, Burnett \& Hansen (2008); Albelda (2011) also observed that accountants assist decision makers to frame policies and to set basic structure to achieve long-run sustainability. But in the small-scale organizations, accountants just perform the traditional accounting roles and do not need to provide any sort of assistance regarding sustainability issues Parker (2000). Accountants in Bangladesh believe organizations need to retain talented and resourceful employees for their own benefits as quality of service depends on the efficiency and effectiveness of the service providers. They expect companies to follow the prevailed rules that not only ensure quality of service and interest of stakeholders simultaneously but also help companies to access financial market smoothly. Sustainability considerably depends on the proper utilization of limited resources by reducing the amount of wastages. Organizations need to discharge their due obligations to the society and environment through corporate social responsibility at the same time earn considerable profit. In a management dominated atmosphere like Bangladesh, accountants feel necessary management support is a must to implement sustainability practices. Lack of appropriate guidelines hampers smooth practice of the same. Since practicing sustainability involves costs, it is unnecessary for the small-scale companies. Sustainability practices in Bangladesh do not give any direct benefits to the companies as customers are not concern about the various aspects of sustainability, environment pollution and responsibilities of companies toward the stakeholders at large. Despite all these barriers, accountants are very much concern about sustainability and longing to help top management to turn their traditional organizations to sustainable organizations through required assistances. However, this study considered small number of samples from selective organizations based in Chittagong only. More samples from different parts of the country would increase the acceptability. 


\section{References}

Albelda, E. (2011). The role of management accounting practices as facilitators of the environmental management: Evidence from EMAS organizations. Sustainability Accounting, Management and Policy Journal, 2(1), 76-100. https://doi.org/10.1108/20408021111162137

Aras, G., \& Crowther, D. (2008). Governance and sustainability: an investigation into relationship between corporate governance and corporate sustainability. Management Decision, 46(3), 433-448. https://doi.org/10.1108/00251740810863870

Azim, M. I., Ahmed, S., \& Islam, M. S. (2009). Corporate social reporting practice: evidence from listed companies in Bangladesh. Journal of Asia-Pacific Business, 10(2), 130-145. http://dx.doi.org/10.1080/10599230902885556

Azim, M., Ahmed, E., \& D'Netto, B. (2011). Corporate social disclosure in Bangladesh: A study of the financial sector. International Review of Business Research Papers, 7(2). Retrieved from http://hdl.cqu.edu.au/10018/916191

Battacharya, C. B., Sen, S., \& Korschun, D. (2008). Using corporate social responsibility to win the war for talent. MIT Sloan Management Review, 49(2), 37-48. Retrieved from https://ssrn.com/abstract=2333549

Brundtland, G. H. (1987). Report of the World Commission on environment and development: "our common future". United Nations.

Burnett, R. D., \& Hansen, D. R. (2008). Ecoefficiency: Defining a role for environmental cost management. Accounting, Organizations and Society, 33(6), 551-581. https://doi.org/10.1016/j.aos.2007.06.002

CIMA (Chartered Institute of Management Accountants). (1981). CIMA Official Terminology, CIMA, London.

Dimitrov, D. K., \& Davey, H. (2011). Sustainable development: what it means to CFOs of New Zealand. Asian Review of Accounting, 19(1), 86-108. https://doi.org/10.1108/13217341111130579

Miyan, M. A. (2006). Dynamics of corporate social responsibility-Bangladesh context.

Myburgh, J. E. (2001). The informativeness of voluntary disclosure in the annual reports of listed industrial companies in South Africa. Meditari Accountancy Research, 9, 199-216. Retrieved from http://hdl.handle.net/10520/EJC72610

Parker, L. D. (2000). Environmental costing: A path to implementation. Australian Accounting Review, 10(22), 43-51. https://doi.org/10.1111/j.1835-2561.2000.tb00069.x

Porter, M. E., \& Kramer, M. R. (2003). Corporate philanthropy: Taking the high ground. Foundation Strategy Group, 13.

Tilt, C. A. (2009). Corporate responsibility, accounting and accountants. In Professionals' Perspectives of Corporate Social Responsibility (pp. 11-32). Berlin Heidelberg: Springer. https://doi.org/10.1007/978-3-642-02630-0_2

Ullah, M. H., Yakub, K. M., \& Hossain, M. H. (2013). Environmental Reporting Practices in Annual Report of Selected Listed Companies in Bangladesh. Research Journal of Finance and Accounting, 4(7), 45-58.

Wilmshurst, T. D., \& Frost, G. R. (2001). The role of accounting and the accountant in the environmental management system. Business Strategy and the Environment, 10(3), 135-147. https://doi.org/10.1002/bse.283

\section{Copyrights}

Copyright for this article is retained by the author(s), with first publication rights granted to the journal.

This is an open-access article distributed under the terms and conditions of the Creative Commons Attribution license (http://creativecommons.org/licenses/by/4.0/). 